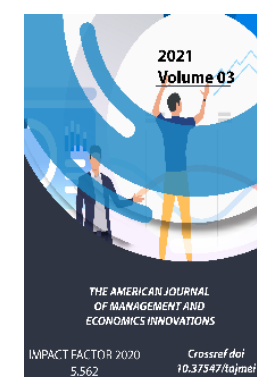

\title{
The Role And Importance Of Hotel Farms In The Development Of Competition
}

\author{
Rakhimov Hasan Abdusaitovich \\ Teacher Of Samarkand Institute Of Economics And Service, PhD, Uzbekistan
}

Journal Website:

https://theamericanjou

rnals.com/index.php/ta

jmei

Copyright: Original

content from this work

may be used under the

terms of the creative

commons attributes

4.0 licence.

\section{ABSTRACT}

This article is an integral part of the tourism and hotel industry. The growing demand for hotels is directly related to the development of tourism. The expansion of hotel activities does not happen by itself. It is known from the world practice that the development of tourism leads to the growth of the country's economy, the development of underdeveloped areas, the growth of employment, the growth of the culture of the population, and so on.

\section{KEYWORDS}

Tourism, hotel industry, employment, GDP, industry, entrepreneurship, services, economic growth.

\section{INTRODUCTION}

Tourism is an industry in which the economy of the country develops, and the social life of the country improves. As a result, many countries have become tourist centers. The economic development of such countries is mainly due to tourism. The hotel management system, which is an integral part of the industry, has also been formed as a network.

\footnotetext{
1 Kudratov G.H., Musaev H.H. Uzbekistan's investment policy and its role in the
}

It is known that our country has a great tourist potential. This is a huge opportunity to boost the economy. However, such opportunities have not been fully exploited. According to some scientists and the media, the share of tourism in the country's GDP is $1.8 \%$. However, the share of this indicator is much higher in developed countries. For example, $12 \%$ in

development of the tourism services market. // Socio-economic problems of tourism market 
Spain, $10 \%$ in the Arab Republic of Egypt, $8 \%$ in Greece, $8 \%$ in the Federal Republic of Germany, $6-7 \%$ in France, $6.2 \%$ in India, $5 \%$ in Singapore, Belgium, USA $3 \%$. It is obvious that our country, which has rich tourist resources, still has great potential for the development of tourism and the hotel industry.

Another important aspect of the development of this sector for Uzbekistan is that it is also a decisive factor in the employment of the unemployed in rural areas of the country. This is because many traditional types of services that are attractive to private entrepreneurship are gradually developing in both urban and rural areas. However, until recently, no effective measures have been taken for the development of tourism and hotel industry in rural areas. In this regard, the President of the Republic of Uzbekistan on April 17, 2006 adopted a resolution "On measures to accelerate the development of the service sector in the Republic of Uzbekistan in 20062010."

development in Uzbekistan. Monograph. - T .: "Economy" Publishing House, 2012. - Pages 288-289.

${ }^{2}$ Resolution of the President of the Republic of Uzbekistan dated April 17, 2006 "On measures to accelerate the development of the service sector in the Republic of Uzbekistan in 20062010". "People's word". April 18, 2006. p.1.

3 Statistical Bulletin of Uzbekistan. 2005. Page 5

${ }^{4}$ Khalikulov N.N. Opportunities to improve the quality and efficiency of service in hotels.
In this decision, he gave a strong task to the local authorities, which was a great impetus for the development of the industry. In particular, the resolution said: "It is absolutely intolerable that the heads of local authorities do not pay enough attention to this important sector."2 Of course, the efficiency of the neglected industry will also be commensurate. The share of the service sector in GDP in 2005 was 38.3\%3. By 2010, this figure was set at 49.0 percent, and we have achieved this. But this is still rare. Because, as we have seen above, in the developed countries of the world, the share of service sectors in GDP is $60-80 \%$. $70 \%$ of the population employed in the economy of these countries work in this service sector ${ }^{4}$.

The lack of rapid development of the service sector in our country has also affected the structure of consumer spending. The share of services in the structure of consumer spending of the population of the country in 2005 was only $15.4 \%$. However, the rate of this figure is not less than $50-60 \%$ in developed countries 5 .

Dissertation for the degree of Candidate of Economic Sciences. SamISI. - 2011. - Page 11, Pardaev M.K., Khalikulov A.N., Rahimov H.A. Problems of increasing efficiency in hotel farms. Monograph. - T .: "Economy" Publishing House, 2013. - 44 pages.

5 Ўзбекистон Республикаси Президентининг 2006 йил 17 апрельдаги “Ўзбекистон Республикасида 2006-2010 йилларда хизмат кўрсатиш ва сервис сохасини ривожлантиришни жадаллаштириш чоратадбирлари тўғрисида"ги қарори. «Халқ сўзи». 2006 йил 18 апрел.1-бет 
The establishment of tourist centers in mountainous and rural areas will help to develop these areas and improve the living standards of the population.

In recent years, in many countries, especially in our country, it has become customary for people living in cities to go to the countryside on weekends for recreation. This has led to the fact that the rural population is required to have a second specialization related to tourism and to build and operate tourist complexes in the picturesque areas of the village. This, in turn, will improve the living conditions of the rural population.

With the expansion of tourism, the number of service enterprises, including hotels, will continue to grow. In addition, the field related to the development of tourism includes many enterprises, businesses (catering, transport, entertainment facilities, etc.), which operate during the tourist season. Their turnover increases depending on the number of tourists.

\section{REFERENCES}

1. Kudratov G.H., Musaev H.H. Uzbekistan's investment policy and its role in the development of the tourism services market. // Socio-economic problems of tourism market development in Uzbekistan. Monograph. - T .: "Economy" Publishing House, 2012. - Pages 288-289. This information is also given in the monograph Pardaev MK, Khalikulov AN, Rakhimov HA "Problems of increasing efficiency in the hotel industry" ( $T$ : "Economy" Publishing House, 2013. - p. 44).

2. Resolution of the President of the Republic of Uzbekistan dated April 17, 2006 "On measures to accelerate the development of the service sector in the Republic of Uzbekistan in 2006-2010". "People's word". April 18, 2006. p.1.

3. Statistical Bulletin of Uzbekistan. 2005. Page 5

4. Khalikulov A.N. Opportunities to improve the quality and efficiency of service in hotels. Dissertation for the degree of Candidate of Economic Sciences. SamISI. 2011. - Page 11.

5. Social development and living standards of the population in Uzbekistan 2004. T .: Goskomstat of Uzbekistan. 2005.-C 72. 